\title{
遷移帯の特性に着目した 硬化体の物質移動特性のモデル化
}

\author{
加藤佳孝 $^{1} \cdot$ 魚本健人 ${ }^{2}$ \\ ${ }^{1}$ 正会員 東京大学生産技術研究所 助手 (下106-8558 東京都港区六本木7-22-1) \\ ${ }^{2}$ 正会員 工博 東京大学国際・産学共同研究センター 教授（テ106-8558 東京都港区六本木7-22-1）
}

\begin{abstract}
セメント硬化体の耐久性能を把握するためには，物質移動特性をシミュレートすることが必要不可欠であり，この 際，硬化体の不均一性を考虑するこ之か重要である. 本研究では，硬化体の物質移動に多大な影響を及ぼすと言われ ている迷移帯の連結性を森林火災理論によって表現し定量的評価を行った. その結果，連結性の急激な増加をもたら す骨材量は水セメント比によって異なることかかかったささらに，硬化体を構成する要素毎の移動俰数を用い，浸透 理論に時間項を組み込むことによって全体系の物質移動特性を表現するモテルの構築を試みた 現時点ては移動現象 の再現においては定性的な表現に留まったが, 実駼結果から得られた傾向を再現することは可能であり，本手法 か妥当であることを検証した。
\end{abstract}

Key Words: transition zone, mass transport properties, connectivity of transition zone, coefficient of mass transport, percolation burning algorithm

\section{1. はじめに}

土木構造物の有効な設計手法として性能照查型設計手 法の概念が提案され，今後の設計方法が構造設計と耐久性 設計の融合であることは，全ての土木技術者か認識してい ることであり, 否定するものはいないであろう. つまり， 今後の研究の方向性としては,これまでなされてきている 構造工学・耐久性の個々の分野において, 相互の融合を意 識したより一般性のある定量的評価を行うことができる ような研究を詳細に進めていくことにあると言える。

本研究では，以上のような背景を踏まえコンクリート 構造物の耐久性設計着眼し研究を遂行した. コンクリー 卜構造物の耐久性能を考えた場合, 塩害, 中性化、凍害, アルカリ骨材反応等の劣化要因が挙げられるが,これら全 ての事象は対象物質は異なるがコンクリート構造体中の 物質移動現象が多大な影響を及ぽす現象であると言える。 つまり, 耐久性設計を定量的に行うためには，硬化体の物 質移動現象を定量的に把握することが重要であるここれ でセメント硬化体の物質移動特性を表現する指標として は，硬化体全体を表現する搪散俰数力多く用いられてきて いる. しかし，セメント硬化体の物質移動を規定する空間 的な特性に依存した要因 (吸着, 化学的現象等を無視した 場合)を厳密に捉えると以下のように大別できると考えら れる. (1)物質移動の基本的性質を規定すると考えられる内
部組織構造を構成する個々の細孔径毎に求まる移動係数 (抎散係数等)，(2)硬化体内に個々に規定された移動係数 が空間的によ゙のように配列しているかによって影響され る空間的影響. つまり, 従来までの拡散俰数はあくまでも 硬化体全体を表現する “見かけの抬散㐿数”であり, 上記 した2つの要因を包括した指標である. そのため，配合条 件等力変化した場合, 汎用性に欠ける表現方法であると考 えられる. また, コンクリートは数種の材料によって桠成 される複合材料であり，本来硬化体の物性は“場所的不均 一性”を有しているが,これまでの多くの研究は硬化体の 物質移動特性を “見かけの搪散係数”によって規定し，コ ンクリート硬化体を“均一”之して取り扱っている場合が 殆どである. このような場合，実際の耐久性能をシミュレ 一トすると様々な不都合が生じる. 例えば, 鉄笳コンクリ 一十の鉄笳腐食を考えた場合, マクロセル腐食は鉄筋自身 やその䚋境の不均一性により鉄筋上に電位差が生じ，その 結果電池加形成され腐食するむのである.ここで，コンク リート中の塩化物イオン等の拡散係数として見かけの拡 散㐿数を全体に均一に与えた場合, 不動熊皮膜の破壊を再 現することはできるが，腐食にとり肝心な“電位差”を生 しさせることは不可能である（無論、ひび割れ混入等によ 万硬化体の不均一性、鉄筋側の不均一性，不動態皮膜の不 均一性等を取り込ぬば可能ではある)。つまり,コンクリ 一ト楧造物の耐久性能を評価する場合には、コンクリート 
の主たる特性である “不均一性”を再現することが必要不 可欠となる. 遷移帯はその特性がセメントペーストの性質 之異なることを考えると，不均一性の代表的要因として捉 えることができ, 存在量はぺースト，骨材等に比して少な いが非常に重要な因子であることは言うまでもない，また， 物質移動特性にとり遷移帯の連結性も無視できない 要因 である.

本研究ではコンクリート構造物の耐久性能に多大な影 響を及ぼす“物質移動特性”を“物質の通り道”，“硬化

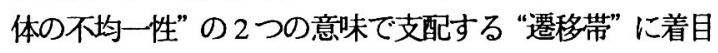
し硬化体の耐久性を論じることが極めて重要であると考 えた. 物質移動は上記したように, 空間的特性に着目した 場合個々の移動係数とそれが空間的にどのように配置さ れているかの 2 つの要因に依って支配されていると考え ることができ, 前者の移動係数に関しては既に報告してい る1). 本研究では, 既報により定量的に評価した遷移帯の 特性 ${ }^{1)}$ を踏まえ, 硬化体を構成する要素の空間的特性力硬 化体の物質移動特性に与える影響を数值シミュレーショ ンによって表現することを目標とした.

\section{2. 物質移動特性の実験的検討}

\section{(1)実験概要}

本研究では，硬化体中の物質移動特性の把握として, 塩 化物イオンの浸透を例に取り実験的検討を行う. 実験に用 いた材料は，研究用セメントおよび標準砂（JIS-R-5201） である. 対象とした配合は，W/Cを 0.5，0.6の 2 種類 細骨材実積率割合 (Vs/Vslim, Vs: 細骨材体積割合, Vslim : 細骨材実積率で $67.6 \%$ ） $0,0.3 ， 0.5 ， 0.7 ， 0.8 ， 0.9$ の 種類とした，供試体数は各条件 2 個とし，供試体の寸法は $\phi 100 \times 100 \mathrm{~mm}$ とし，ブリーディングの影響を極力排除す るために練返しを数回行った. 打設完了後䄪 1 日間湿潤養 生を施し, 脱型後 $20^{\circ} \mathrm{C}$ 水中盖生て材秢 28 日まで盖生を行 った. 材羭経過後にカッターにより約 $25 \mathrm{~mm}$ の厚さに切 断し,切断後真空ポンプを用いて供試体を飽水状態とした. 飽水状態とした供試体を图-1 に示す拡散セルにセットし， 一方のセルに $\mathrm{NaCl3 \%}$ 溶液を満たし, 他方のセルには飽水 時に用いたもの亡同様な水(水道水)を満たした. その後,

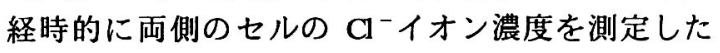
(SALMATE-100 使用) . 測定期間は何れの供試体も 20 日間とし，測定間隔は2〜3 日とした。

\section{(2)塩化物イオンの移動度の算出方法}

図-2 にセメントペーストの場合のセル中の塩化物イオ 濃度の経時変化を示す. 上図が $\mathrm{NaCl} 3 \%$ 溶液側, 下図が 水側のセルの濃度変化を示している. $\mathrm{NaClB} \%$ 溶液側のセ

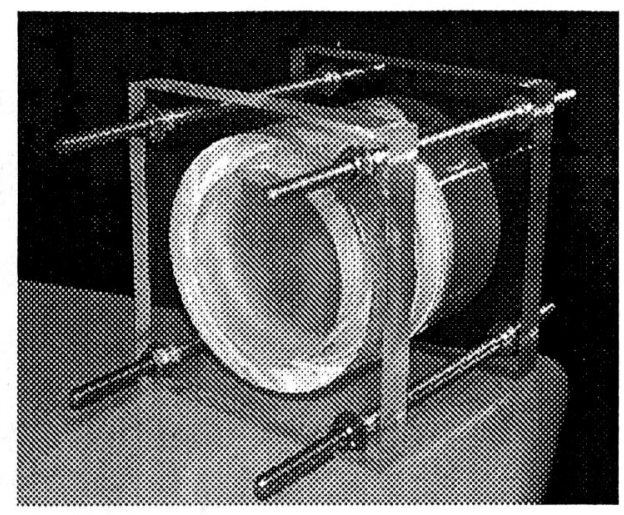

図-1搪散セル全体図

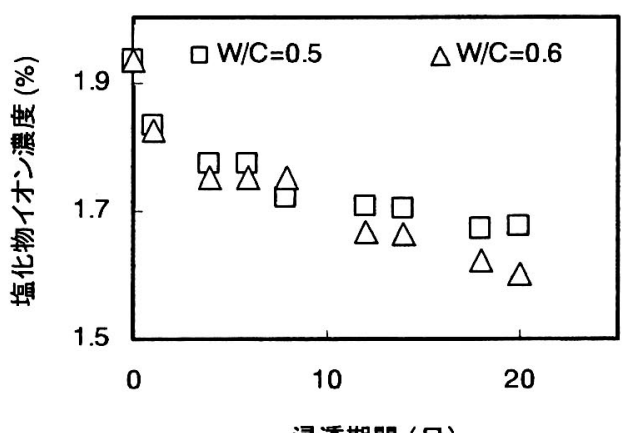

浸透期間（日）

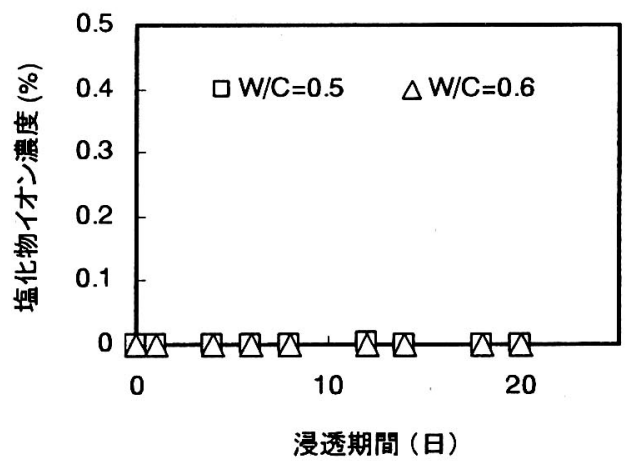

図-2 測定結果の一例（セメントペースト）

ルは浸透期間の経過とともに濃度が減少しているのに対 し, 水側のセルの濃度は殆と変化していないことがわかる. 通常, 拡散セルを用いた試験より得られる結果としては対 象とした物質の拡散係数がある.これは式(1)を用いて算 出することができる.

$$
D=\frac{L}{A \cdot C_{0}} \frac{d Q}{d t}
$$

ここに,

$\mathrm{D}$ : 拡散係数, $\mathrm{L}$ : 供試体厚さ, $\mathrm{A}$ ：供試体断面積 


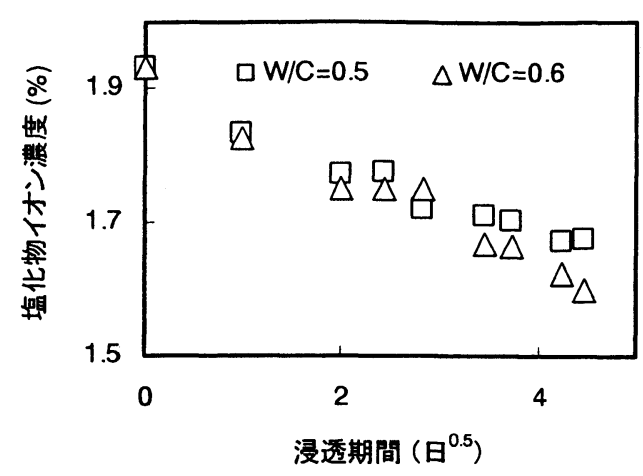

図-3 塩化物イオン濃度の経時変化 (時間軸 $\sqrt{t})$

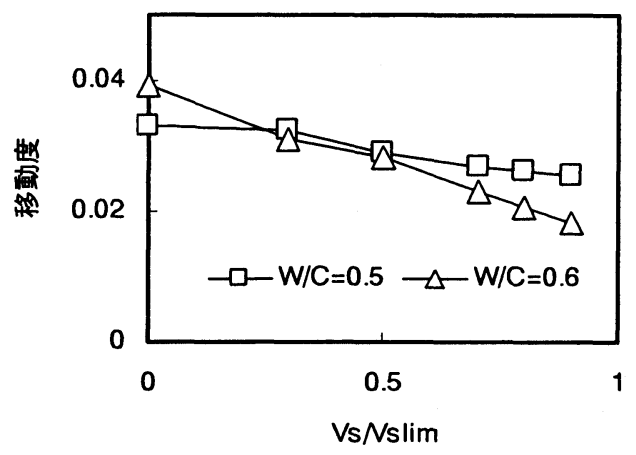

図-5 塩化物イオンの移動度

$\mathrm{C}_{0}: \mathrm{NaCl} 3 \%$ 溶液側の塩化物イオン濃度 $\mathrm{dQ} / \mathrm{dt}:$ 水側の濃度変化率

拡散係数は，式(1)に示すように対象とする物質の濃度 変化によって算出されるものであり, 対象物質がセルの中 央部に配した供試体を通過することによって初めて求め ることができる. しかし，図-2 の下図を見れば明らかな ように, 本研究で対象とした測定期間内では供試体を通過 して塩化物イオンが水側のセルに移動していないことが わかる. つまり, 本研究の場合式(1)によって拡散係数を 算出することは不可能である. そこで, 本研究では $\mathrm{NaCl} 3 \%$ 溶液側の塩化物イオン濃度の減少に着目し以下に 示す方法によって, 材料条件の違いか塩化物イオンの移動 に与える影響を把握する. 图-2 の上図より，塩化物イオ ン濃度の減少速度は浸透期間初期に速く後期においては 緩やかな変動を示す. また, 中性化の浸透深さ等の拡散現 象による浸透深さは一般に $\sqrt{\mathrm{t}}$ ( $\mathrm{t}$ : 時間) と比例関係に あることが知られている2゙.ここで，一般的な中性化深さ の経時変化 (時間軸は普通軸) を見ると, 傾向としては実 験結果で得られた $\mathrm{NaCl}$ \%溶液側の塩化物イオンの減少 傾向之類似していることがかかった. そこで，図-2 の上 図の横軸を $\sqrt{\mathrm{t}}$ とした結果を図-3に示す. 図から明らかな

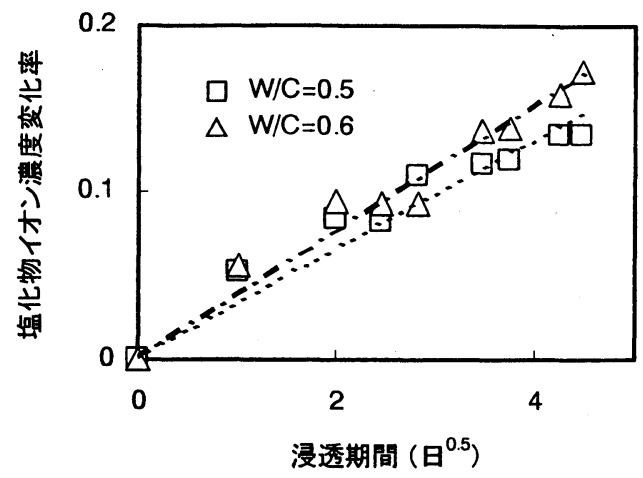

図-4 塩化物イオン濃度変化率の経時変化 $($ 時間軸 $\sqrt{\mathrm{t}})$

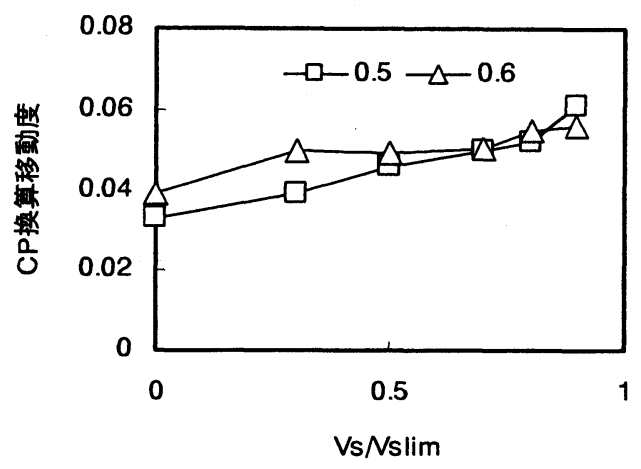

图-6 塩化物イオンのCP換算移動度

ように両者の関係はほほ直線関係にあることがわかる.そ こで, 本研究ではこの直線の傾きを塩化物イオンの移動を 代表する指標とし，以下この值を用いて考察を行う.また， 初期塩化物イオン濃度で全ての濃度を正規化し, 初期塩化 物イオン濃度からの濃度変化率として塩化物イオン濃度 を変換した結果を図-4 に示す．両者の関係は正比例の関 係として捉えることができ，以降この直線の傾きを移動度 と定義し, 材料条件の影響に関して考察を行う. 本研究に おいて,物質の移動を示す指標をこのように設定したのは, 4 章で提案する物質移動のモテル化が浸透理論に基つい たものであるためである. 浸透理論を用いた場合, 物質移 動は通常考えられる搪散現象之は少し意味が異なり, 硬化 体全体の特性を示すと言うよりは，局部的な特性を重視し た場合の物質の通り易さを表現していると考えられる.つ まり,物質移動現象に関しては初期の濃度変化に着目する ことにより, 用いるモテルに即した実験を行うことが可能 であると考えたためである.

\section{(3)材料条件が塩化物イオンの移動度に与える影響}

前項で定義した塩化物イオンの移動度の結果を图-5に 示す. W/C 0.5, 0.6 ともに細骨材実積率割合の増加に伴い 塩化物イオンの移動度は減少傾向にある. これは, 塩化物 
イオンの移動経路とは考えられない細骨材の存在が,多く なったためであると考えられる.W/C 0.5 の場合細骨材実 積率割合が 0.3 程度では，移動度がセメントペーストの場 合と殆と変わらないことがわかる. これは，骨材が混入す ることにより移動経路となるセメントペーストのネット ワークが分断され始めるのであるが, 骨材量が少ない領域 ではその影響が少ないためであると考えられる.さらに, W/C 0.5 の場合において見られるが，塩化物イオンの移動 度は細骨材実積率の增加に対して一定の割合で減少する のではなく, 細骨材実積率割合 0.7 付近でその減少傾向が 緩やかになることがわかる.これは，塩化物イオンの移動 経路として考えられる部分 (セメントペースト, 遷移帯) の空間的配列特性が細骨材実積率割合の増加之伴に変化 することによって生じた結果であると考えられる. そこで, 骨材量の影響を排除するために, 求めた塩化物イオンの移 動度をモルタル中のセメントペーストの体積割合で正規 化したもの (CP 換算移動度と略記) を图一に示す.ここ で,セメントペーストの体積割合は配合によって決定され る值を用いた，CP換算移動度は細骨材実積率割合の増加 に伴い，増加していく傾向にあることがわかり，增加傾向 は細骨材実積率割合 0.7 付近において，それ以前と比へてて 大きくなるように見える. これは，同一W/C の場合，移 動経路の 1 つであるセメントペーストの性質は同一であ るとすれば,このような傾向の変化は遷移帯の連結性等の 影響であると考えられる. 実験結果におけるW/C の違い を見ると，細骨材実積率割合 0.7 以上の領域で 0.5 および 0.6 のCP 換算移動度かほぼ同一か，もしくは 0.5 の方が高 いという結果になっている (図-6 参照)。単純に考えれ ば, W/Cが高い0.6の方がセメントペーストおよび遷移帯 中の組織は粗であることから，CP 換算移動度も大きな值 を示すと考えられる. これらに関しては，実験結果のばら つきが多いのに対して, 試験体数が少ない点に問題がある 亡考えられ，今後詳細に硬化体の物質移動特性を実験的に 求めていく必要がある. しかしながら, 定性的な傾向を追 随することが主目的である本研究においては, 参考値とし て使用することは可能であると判断した.

\section{3. 遷移帯の連結性に関する定量的検討}

本章では，従来から物質移動現象に多大な影響を及ぼす とわれている遷移帯の連結性に関して数值シミュレーシ ヨンによって定量的に評価する. 本研究における解析手法 は，3次元空間内に遷移带を周囲に保有した骨材 (形状は 球形と仮定)をランダムに配し, 浸透経路としては遷移帯 のみを考虑し, 上面から浸透を開始した場合における浸透 に関与した遷移帯数を解析的に求めることによって遷移

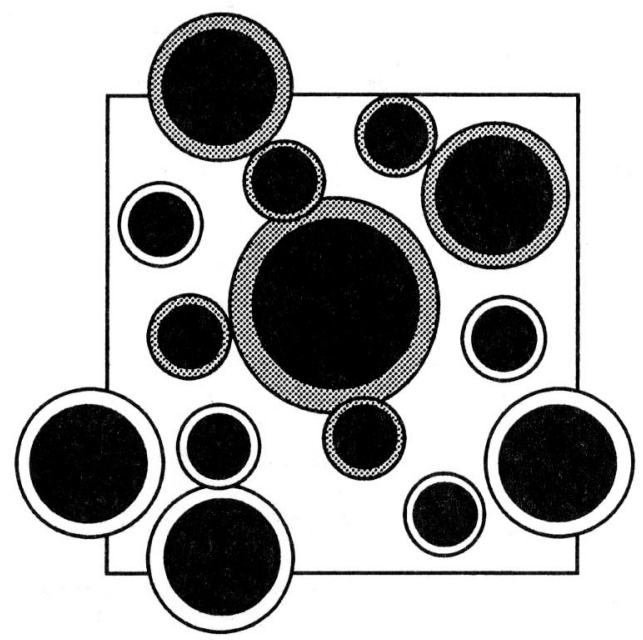

図-7 2 次元における浸透概念図

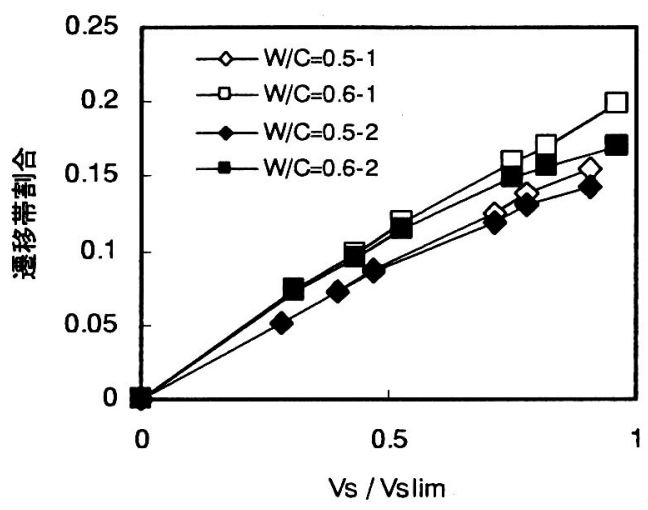

図-8 細骨材実積率割合之遷移帯割合の関係

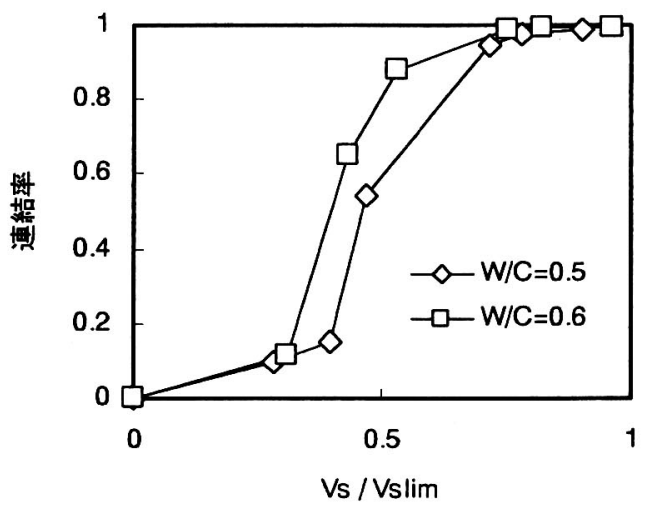

図-9 細骨材実積率割合之遷移帯連結率の関係

帯の連結性を表現するものである. 図-7に 2 次元空間に おける解析の概念図を示す.図中の黑色の領域力桜冏材を 示し, 骨材周囲に配置された白色の領域か遷移帯を示して いる. 上面から遷移帯中を浸透するとした場合, 図中の灰 
色になった遷移帯領域に浸透することとなり, 遷移帯の連 結率とはこの浸透に寄与した遷移帯量を解析対象範囲内 の全遷移帯量て除したものである. 以下に解析条件を示す. <解析条件>

(1)解析対象範囲 : $150 \times 150 \times 150($ pixel)

(2)細骨材粒径: 細骨材実積率割合 0.9 程度の細骨材が混入 可能となるように粒径が $1.55,1.29,1.09,0.93,0.78,0.57$, $0.32,0.15(\mathrm{~mm})$ の 8 種類の細骨材が存在するとして表現 する.

(3)遷移帯厚さ:解析加求まる骨材径毎の遷移帯厚さを体 積平均して, 粓径の異なる骨材に対し同一の厚さの遷移帯 を配する(厚さはW/C, 骨材径, 量に依存するが $24 〜 33 \mu \mathrm{m}$ 程度) ${ }^{1)}$.

(4)1pixel の大きさ : 1pixel の大きさは解析対象ケースの最 小スケールユニットである遷移帯厚さとする.

以上の条件に基づき, 周囲に遷移帯を配した細骨材を解 析対象内に骨材径の大きいものからランダムに配置する. 配置の際, 骨材同士の重なり合いは許さないが, 遷移帯同 士および遷移帯と骨材の重なり合いは許す.解析の対象を 硬化体からある部分を切り出した場合とするために, 上下， 左右面を連続として取り扱う. 遷移帯を配した細骨材の配 置終了後, 遷移帯の連結性を森林火災理論のアルゴリズム を用いて計算する ${ }^{3}$. なお, 解析回数は 100 回であり結果 はその平均値を用いている.

図-8に細骨材実積率割合と遷移帯割合（全体積に対す る遷移帯の割合) の関係を示す. 図中白抜きの印が, 細骨 材の粒径毎に求まる遷移帯割合を単純に足しあわせた量 を示し, 黒塗りの印が 3 次元に配置された遷移帯同士およ び細骨材と遷移帯が重なり合うことによってその割合を 減少させることを考虑したものである. なお, 解析の対象 は細骨材実積率割合 $0.3,0.5,0.7,0.8,0.9$ と設定はして いるが, 実際に解析範囲内にある限られた大きさを持った 細骨材を配置しているために,多少想定した細骨材量と異 なるが解析結果では実際に配置された量から細骨材実積 率割合を算出している. 図から明らかなように, 細骨材実 積率割合0.5 付近までは重なり合うことによる遷移帯量の 滅少は殆ど見られず, その後減少量が増加していきこの傾 向はW/C 0.6 の方か灝著であることがわかる. 結果として, 遷移帯量はある值に漸近するように変化していることが わかる. 図-9 に細骨材実積率割合之遷移帯連結率の関係 を示す. なお, 細骨材実積率割合 0.3 から 0.5 にかけて遷 移帯連結率が急激に增加したため, 細骨材実積率割合 0.4 程度の解析を追加して行った. 遷移帯連結率は, 何れの W/C ともに細骨材実積率割合の増加と伴に増加する傾向 にあり, W/C 0.5 では 0.4 付近, W/C 0.6 では 0.3 付近の細 骨材実積率割合において, 急激に増加し 0.7 付近でほほ全 ての遷移帯が連結することになることがわかる。
表-1 構成要素の移動係数比率

\begin{tabular}{|c|c|c|c|c|}
\hline \multirow{2}{*}{} & \multirow{2}{*}{$\mathrm{CP}$} & \multicolumn{3}{|c|}{ 畺移帯 } \\
\cline { 3 - 5 } & & LS & MS & SS \\
\hline $\mathrm{W} / \mathrm{C}=0.5$ & 1.0 & 5.7 & 1.6 & 1.2 \\
\hline $\mathrm{W} / \mathrm{C}=0.6$ & 1.2 & 16.7 & 2.0 & 1.4 \\
\hline
\end{tabular}

\section{4. 構成材料の空間的特性に着目した物質移動の モデル化}

\section{(1)便化体構成要素の移動係数 ${ }^{1)}$}

セメント硬化体の物質移動は, セメントペーストおよび 遷移帯によって主に支配されている. そのため, 硬化体全 体の移動特性を把握するためには，全体系としての見かけ の移動係数を把握するよりも, 構成要素毎の移動特性を把 握することの方が, 正確であり汎用性を有していると考え

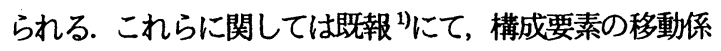
数を算出する方法を提案した. ここで言う移動係数とは, 拡散係数のように次元を持った定量的な値ではなく, 移動 のし易さを示す程度の値であり, 移動係数が大きいほど移 動がし易いことを示している. 表-1 にセメントペースト および遷移帯の移動係数を示す (W/C 0.5 の移動係数を 1 としてこれに対する比率で示してある).ここで, 遷移帯 の特性は骨材の大きさに影響を受けるため, 遷移帯の移動 係数は骨材径毎に求めてある（表中 LS, MS, SS は細骨 材の平均粒径を意味しそれぞれ $1.44 ， 0.89 ， 0.35 \mathrm{~mm}$ であ る).

\section{(2)遷移帯を考慮した硬化体物質移動特性のモデル化}

本項では, 既報で求めたセメントペーストおよび遷移帯 の移動係数 ${ }^{1)}$ を用いて, 硬化体の物質移動特性をモデ化 することを試みる. 物質移動のモデル化の手法としては, 前章に記した森林火災理論による浸透理論を用いて表現 することとした. 基本的な解析条件は前項と同じであるが， 一般に森林火災理論等の浸透理論は空間的特性を把握す ることには適しているが, 時間を含む問題に関してはどの ように時間項を組み込むかが難しいとされている. そこで, 本研究では以下に示す概念の基に森林火災理論に時間項 を組み込むこととした。お，解析上では物質が浸透する 時間を対象とするため, 速度的意味合いを持つ “構成要素 毎の移動係数” の逆数（“移動時間係数”）を用いること により表現する. さらに, 硬化体全体における物質移動の 評価には, 構成要素の空間的要因を含むためその結果であ る浸透時間を “時間係数”之定義する. 最終的に, 従来用 いられている “拡散係数”之の意味を同等にするために， 時間係数の逆数を用いて速度論的な取り扱いが可能であ る “平均移動係数”を用いることとする.

3 次元空間に各構成要素 (骨材, セメントペース卜, 遷 


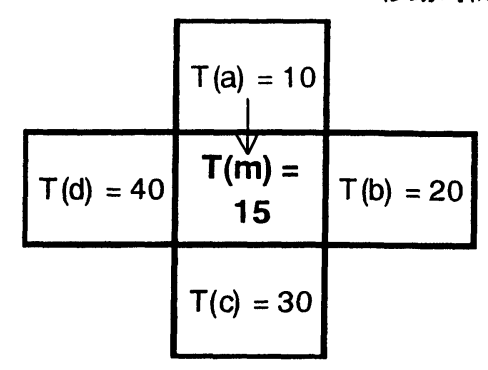

供給元のSTEPが判定と同一の場合

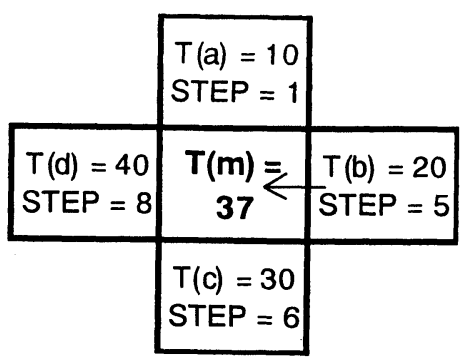

供給元のSTEPが判定と異なる場合 (判定STEP = 8 )
各要素の供給時間係数 $a=10+10 / 1^{\star}(8-1)=80$ $b=20+20 / 5^{\star}(8-5)=32$ $c=30+30 / 6 *(8-6)=40$ $d=40+40 / 8^{\star}(8-8)=40$

図-11 各要素間の時間係数の供給方法の概念図

拡散的流れ

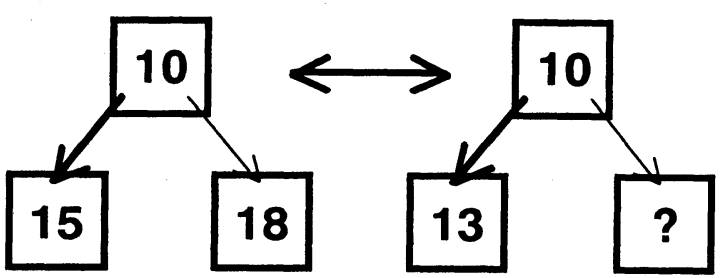

図-10 拡散流れ之本研究での流れの違い概令図

移帯) か配置されたとき, 物質が各要素間を移動するので あるが, 移動する物質は常に対象とする要素を完全に満た した後, 次の要素に進行すると仮定する. このとき, 各要 素の単位容積を満たすのに費やされる時間は移動係数の 逆数で表現することができるとする. つまり, 各要素を満 たすのに必要な時間（ $\mathrm{Te}(\mathrm{m})$ ：移動時間係数之略記）は 式(2)の形で表現することができる.

$$
T e(m)=\frac{1}{d p e r(m)}
$$

ここに, $\operatorname{dper}(\mathrm{m})$ : 各要素の移動係数 $\mathrm{m}$ : 要素の種類

上面から浸透する状况をモデル化するのであるが, 初期 条件としては上面部の各要素に要素に依存した $\mathrm{Te}(\mathrm{m})$ を 代入する.ここから順次浸透を開始し全ての要素の判定が 1 回づつ終了するまでを 1STEP とする. ここで, 1STEP 内における各要素が隣接する要素へ物質を供給できる回 数は 1 回のみ亡制限する.このような手順を繰り返し行い， 全要素の時間係数(時間係数は上面から浸透してきた物質 が各要素に達するまでの時間と, 移動時間係数 $(\mathrm{Te}(\mathrm{m}))$ を足しあわせたものである)が1つも更新されない状態と なった STEP を移動終了とし解析を終了する. 判定方法は,
ある要素に隣接する6個の要素を供給元として捉え,これ らの要素の中で最も小さな時間係数を持った要素之, 判定 の対象亡なっている要素の時間係数を比較して供給元の 方が小さければ判定の対象となっている要素の時間係数 が更新されると考える.ここで, 供給元が供給されたSTEP と判定を行っているSTEPが同一の場合は, 判定の対象で ある要素の時間係数は“供給元の時間係数+対象要素の移 動時間係数”で求めることができる. しかし, 供給元が供 給されたSTEP と判定を行っているSTEPに差がある場合 は, STEPの時間的意味を考虑しなければならない：この ような問題が生じるのは以下の点に起因する. (1)1STEP 中に供給できる要素は 1 要素のため隣接する要素に平均 的な流れを表現できない：(2)1STEP 中の時間的意味が要 素每に異なる. つまり，一般的な拡散の概念では図-10の 左図に示すように隣接する要素に平均的に物質が流机て いくのに対して, 本解析手法の場合 1 要素ずつの流れであ るため図-10の右図に示すように1要素を満たした後に次 の要素を満たすのにかかる時間を算出する際に, 供給元を 基準に隣接要素で平均化することにより一般的な拡散流 れを表現しようとしているためである. そこで, 本研究で は判定の対象亡なる要素の時間係数を式(3)の形で表現す る.

\section{$T(m)$}

$=T(i)+T e(m)+\frac{T(i)}{S T E P(i)} \times(S T E P-S T E P(i))$

ここに, $\mathrm{T}(\mathrm{m}), \mathrm{T}(\mathrm{i})$ : 判定要素および供給元の時間係数, STEP(i):供給元が供給された STEP, STEP:判定時の STEP

式(3)は，STEP 間の時間的意味を供給元の単位 STEP あ 
たりの時間係数を用いて表現しているものである.以上の 概念を 2 次元空間を例に取り簡単に説明する. 図-11に見 られるように各要素に時間係数が代入されているとする. 供給元が供給されたSTEPが判定時と同一の場合 (左図参 照), 対象となる要素の時間係数は隣接している要素の最 小值である a の要素の “10” に要素の移動時間係数 “ 5 ” を足した “15”として代入される. ここで, 例えば a の要 素のみが既に別の要素に供給していた場合, 最小值は b の要素となり結果として “25”汃入される. 次に, 供給 元が供給されたSTEPが判定時と異なる場合(右図参照), 各供給元の時間係数は図に示したように算出され, 結果と してbの要素から供給されることになり “37”か代入され ることになる. このように, 本モデルにおける時間項は, 隣接した要素の時間係数亡, その供給元の要素が何 STEP 後に初めて供給を開始するかによる夕イムラグを考慮す ることによって表現するようにモデル化している.

\section{(3)解析結果及び考察}

以上のモデルを用いてセメント硬化体全体の物質移動 特性の検討を行った. 解析の対象はW/C0.5, 0.6, 細骨材 実積率割合 $0.3 ， 0.4 ， 0.5,0.7,0.8,0.9$ とした. 本モテル のアウトプットは, 上面から浸透を開始した物質が最下面 に到達するまでの時間を要素毎に算出するものである. 本 モデルは, セメント硬化体の不均一性を考虑したものであ るため, 無論最下面の各要素の解析結果は同一ではない． 全ての解析ケースを比較検討するための指標として, 得ら れた到達時間の逆数をとることによって, 速度論的な取り 扱いか可能となるものを採用した (以下, 平均移動係数亡 略記).ここで比較の対象とした要素は最下面に最初に到 達した要素とした.

解析結果を図-12に示す. 図中 $\square$ 印は, セメントペース ト中に骨材を混入したのみの場合，つまり遷移帯を考虑し ていない場合であり，骨材混入によりセメントペース中の 移動経路のネットワークがどの程度分断されていくかを 示しており， $\triangle \mathrm{E}^{2}$ は遷移帯 $(\mathrm{Tz})$ を考虑したものである. 点線は, セメントペーストのみの移動係数を示している. 硬化体中の骨材混入の影響をみると, W/C 0.5 の場合, 細 骨材実積率割合が 0.5 付近, W/C 0.6 の場合は 0.3 付近ま では, 骨材の混入よる平均移動係数の隇少は見られず, 硬 化体の物質移動に対して殆と影響が無いように思える.こ れは, 比較している対象が最下面に最初に到達した要素で あることを考虑すれば, 骨材の混入によって最短経路が分 断されずに存在しているということを意味しており,決し て全体の平均移動係数が減少していないということでは ない：細骨材実積率割合が 0.5 付近において，セメントペ 一スト中の移動経路の分断か激しくなり, 結果として以降 の平均移動係数が急激に減少していることがわかる.
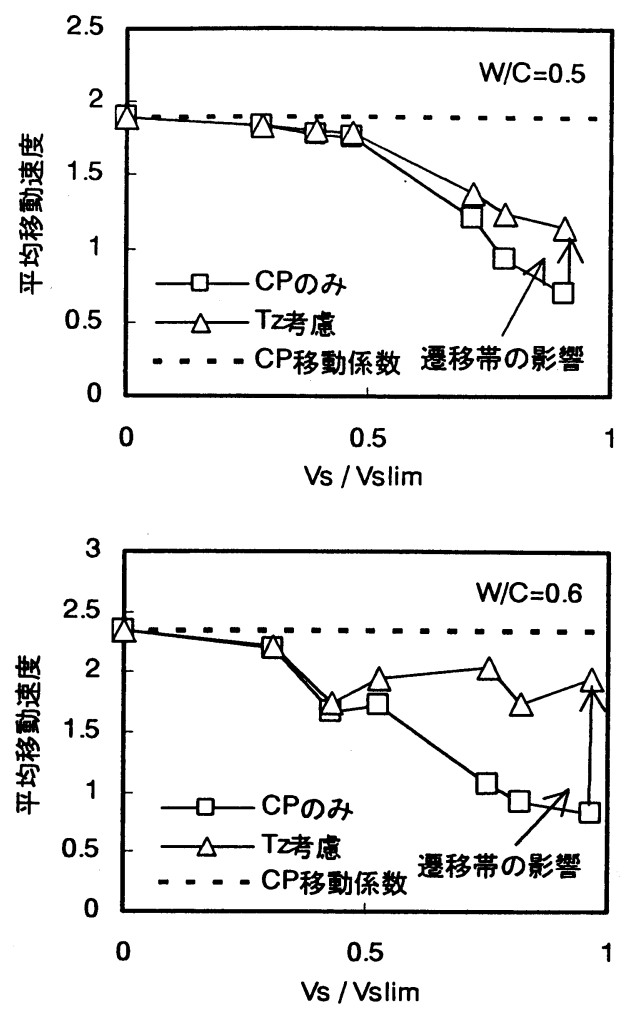

図-12 平均移動係数の解析結果
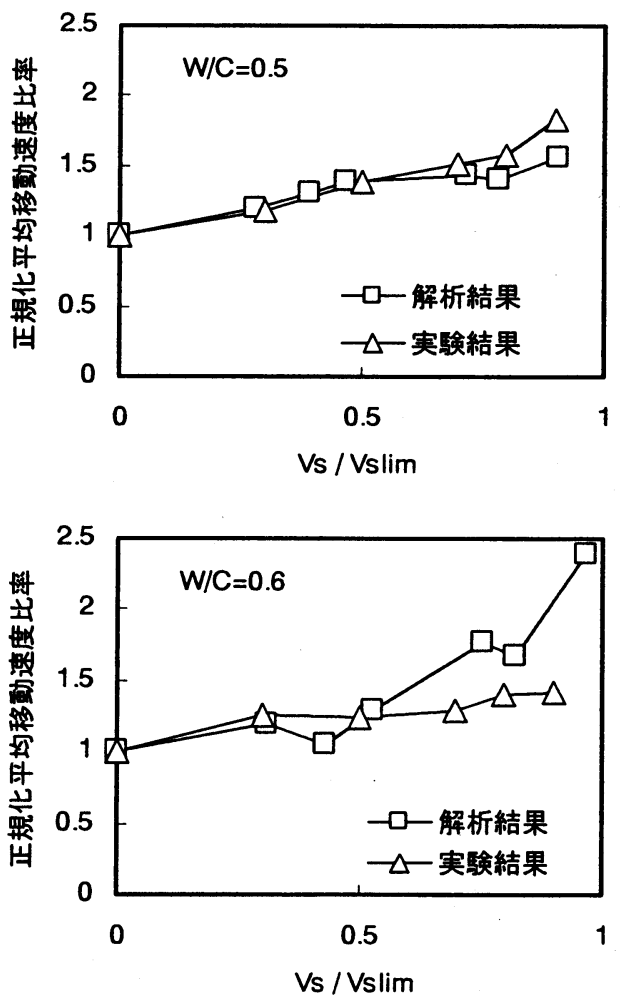

図-13 硬化体移動特性の解析結果之実験結果の比較 
遷移帯を考虑した場合，細骨材実積率割合が 0.5 付近まで は殆ど影響がないことがわかる.ここで，前項で検討を行 った遷移帯の連結率の結果と比較すると（図-9 参照），

W/C 0.5 で約 60\%，0.6で約 90\%の遷移帯が連結している にもかかわらず, その影響か硬化体の移動特性にはさほど 現れていないと言うことがわかる.両者の結果を比較する 之, 遷移帯か硬化体の物質移動に多大な影響を及ぼすのは, ほぼ 100\%の遷移帯が連結した状態であることがわかる. この結果を硬化体中のセメントペースト体積割合で正規 化した結果のセメントペーストに対する比率(正規化平均 移動係数比率と略記）之実験結果の比較を図-13 に示す. 図中 $\square$ 印か解析結果を示し，印が実験結果を示している. なお, 実験結果の移動度も解析結果之同様にセメントペー ストに対する比率で表現した。 これは，解析，実験ともに セメントペーストとモルタルの取り扱いは同様な手法を 用いているため, セメントペーストの特性に対する比率で 表現することによって, 解析結果と䒠駼結果を比較するこ 之が可能であると考えたためである.W/C 0.5 に関しては, 解析結果がほほ実験結果の傾向を再現しており, 本モデル の妥当性か確認された. 実験結果の細骨材実積率割合 0.9 付近の急激な増加减少は, 若干再現できてはいないが，そ れ以外は極めて良好な解析結果である.W/C 0.6 の場合, 細骨材実積率割合が 0.5 付近までは，ほほ害験結果を再現 しているが, その後実験結果は緩やかな増加傾向を示して いるのに対し,解析結果は急激に増加していることがわか る. 解析では, 細骨材の形状を球と仮定している点や遷移 帯が全ての細骨材周囲に存在している点等の多くの仮定 条件が含まれている. 細骨材量が少ないレベルでは, これ らの仮定条件の影響が少ないと考えられ，逆に存在量が多 くなるとその影響が無視できなくなると考えられる.また， 実験結果に見られるように, 現状の実験精度に問題がある と考えられる. 以上のようなことから, 解析結果之実験結 果の差が生じたと考えられるが, 詳細に関しては今後の検 討課題亡する.

最後に，物質の移動現象を構成要素の空間的特性に着目 して表現した結果と,従来までの見かけの拡散係数を用い て表現した場合の違いに関して考察を加える. まず, 既報 によって提案した 3 次元 King のモデ ${ }^{1)}$ を用いて, 硬化 体の物質移動を司る 2 相 (セメントペースト，遷移帯)に おける全体の移動係数を算出する. また, 見かけの搪散係 数亡しては既往の研究より ${ }^{4)}, 1 \mathrm{~mm}$ の疑似骨材とセメン トペーストから構成される硬化体の正規化透気係数(硬化 体全体の透気係数をセメントペーストの体積割合で除す ことにより骨材量の影響を排除したもの) を使用する. 両 者の骨材実積率割合とそれぞれのセメントペーストに対 する比率（移動係数比率）の関係を图-14に示す. 図中○ 印が3次元 King のモテルを用いた結果であり， $\square$ 印が 既

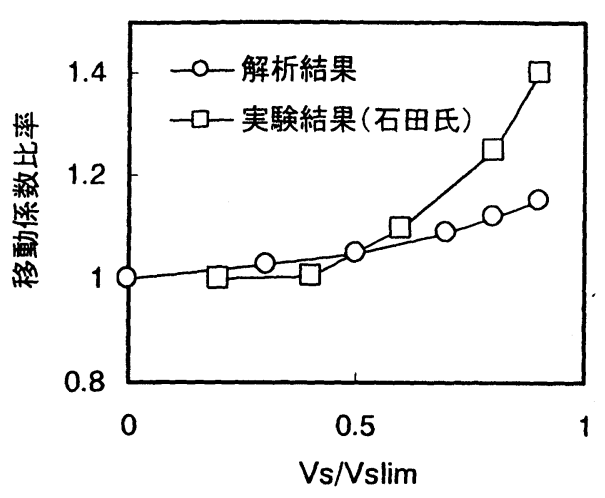

图-14 計算による全体の移動係数之 実験による見かけの透気係数の比較

往の研究による実験結果である. 一般的に, 骨材の混入割 合力硬化体の移動現象に与える影響としては, 図-14に示 したような害験結果で論じる場合, 混入量が少ない範囲の 移動係数はセメントペーストの場合亡ほぼ同一で, ある値 から急激に增加傾向を示す之言われている.この理由とし ては, 従来遷移帯の連結性か㴗因であるとされている.し かし, 透気係数や拡散係数等に代表される物質の移動を示 す指標は, 本来通過する径の大きさや量に依存する物理的 指標であり, 連結性といった空間的問題に影響を受ける物 理量ではない: 一方, 解析によって求めた硬化体全体の移 動係数は, 骨材の混入に伴う遷移帯領域 (径, 容量伴にセ メントペースト部よりも大きい領域)の増加に伴って, 単 調に増加していることがわかる. これは, 移動係数として の物理的意味に即している結果であるといえる. 图-13で 示した解析結果は個々の移動係数之それか配置される空 間的特性を合わせた結果であり，物質移動を支配する 2 つの要因を切り離して考えることにより，それぞれの影響 がどのように作用しているかを把握することができる.つ まり, 骨材の混入割合が少ない範囲内の透気係数がセメン トペーストとほぼ同一であるという現象は, 硬化体中の透 気係数は単調に増加しているのであるが, その空間的配列 により全体の透気係数がセメントペーストの透気係数に 強く支配されている領域であると捉えることができる.さ らに，骨材量の增加に伴う透気係数の急激な増加現象は， 透気係数の增加之物質が移動しやすい空間的配列か形成 されることによって生じる現象であると捉えることがで きる. このように, 本モデルはセメント硬化体の物質移動 現象を物理現象に即した形で表現していると考えられ，従 来の見かけの拡散係数亡比して配合条件等にも柔軟に対 応可能な汎用性を有していると考えられる. 


\section{5. まとめ}

本研究で得られた成果を以下にとりまとめる.

(1)セメント硬化体の単位セメントペースト当たりの移動 度は細骨材実積率割合の増加に伴い，増加していく傾 向にあることが明らかとなった，その増加傾向は細骨 材実積率割合 0.7 付近においてそれ以前と比へ大きく なるように見られる.これは，同一水セメント比の場 合, 移動経路の 1 つであるセメントペーストの性質が 同一であるとすれば，このような傾向の変化は遷移帯 の連結性等の影響であると考えられる.

(2)遷移帯の連結性は水セメント比 0.5 の場合, 細骨材実積 率割合 0.4 付近，水セメント比 0.6 の場合， 0.3 付近で 増加し始め, 細骨材実積率割合が 0.7 程度で殆どの遷移 帯が連結することが明らかとなった。

(3)硬化体の構成材料の物質移動特性および空間的特性に 着目した物質移動のモデル化を提案した. 硬化体全体 の移動特性を浸透理論に時間項を加えることにより表 現した結果，遷移帯による移動速度の増加，骨材混入 による移動速度の隇少傾向をシミュレートすることが できることを示した. 定性的ではあるが解析によって 求めた移動速度と実験結果を比較した結果，本手法の 妥当性を確認することができた。

(4)従来言われている骨材量の増加に伴う拡散係数の急激 な増加現象に関して，本モデルを用いることによって 説明可能であることを示した. つまり, 硬化体中の移 動を司る領域の移動係数は骨材量の增加（遷移帯の増 加）とともに単調に増加するのであるが，構成要素の 空間的配列の結果によって実験結果で求まる急激な增 加現象は生じている.これは，実験結果による見かけ の拡散係数等は構成材料の空間的配列によって強く支 配されていると言うことを示している.
現時点では，本研究で求めた移動俰数，移動速度等の值 はあくまでも定性的な範囲に留まっている. しかし，骨材 の混入に伴う移動係数の急激な増加現象に対して, 理論的 な裹付けがないまま“遷移帯部の連結性が原因である”と 結論つけていた現状に対し,構成要素の特性を定量的に明 らかにした上で,セメント硬化体の不均一性を考慮した物 質移動のモデル化を行い, ある程度の妥当性を持った結果 が得られた本研究は, 本分野における研究成果に貢献した と考えている.

謝辞 : 本研究を実施するにあたり実験を手伝って頂いた， 元千葉工業大学森川雅浩君, 元芝浦工業大学坂本圭司君に 感謝の意を表します. なお，本研究の一部は，平成 10 年 度セメント協会研究奖励金によるものであることを付記 する.

\section{参考文献}

1）加藤佳孝，魚本健人：骨材界面に存在する遷移帯特性の定 量的評価に関する研究，土木学会論文集，No.641/V 46, pp.77-86, 2000.

2）例えば魚本健人，高田良章：コンクリートの中性化速度に 及ぼす要因，土木学会論文集，No.451/V-17, pp.119-128, 1992.

3） D.スタウファー著（小田垣孝訳）：浸透理論の基䃈，吉岡 書店, 1988.

4）石田哲也，前川宏一：物質移動特性からみたコンクリート の微少空隙構造、士木学会第 49 回年次学術講演会講演概要 集第5 部, pp.1020-1021，1994.

\title{
THE MODELING OF MASS TRANSPORT PROPERTIES IN HARDENED CEMENT BASED ON TRANSITION ZONE PROPERTIES
}

\author{
Yoshitaka KATO and Taketo UOMOTO
}

\begin{abstract}
In order to clarify the durability performance of cement composites, it is necessary to simulate mass transport properties, and in this case, it is important to take into consideration the heterogeneity of the hardened cement. In this research, the connectivity of transition zone, which is effective factor for mass transport properties, was expressed by the "burning algorithm". As a result, the sand amount that brings about the rapid increase in the connectivity depends on water cement ratio. And using the coefficient of mass transport and percolation theory, we simulate the mass transport properties in 3-D. Comparing the analytical results with experimental results, this simulation may be effective to evaluate the real condition of mass transport properties.
\end{abstract}

